\title{
Cytokine Receptor Activation
}

National Cancer Institute

\section{Source}

National Cancer Institute. Cytokine Receptor Activation. NCI Thesaurus. Code C45547.

Any interaction between a cog nate lig and and any of a series of cytokine receptors.

Activation of cytokine receptors is involved in regulation of the immune system, cell proliferation, cell death, as well as other multicellular processes. 